University of Nebraska - Lincoln

DigitalCommons@University of Nebraska - Lincoln

USDA National Wildlife Research Center - Staff Publications
U.S. Department of Agriculture: Animal and Plant Health Inspection Service

April 1996

\title{
Evaluation of propane exploders as white-tailed deer deterrents
}

\author{
J. L. Belant \\ US Department of Agriculture, National Wildlife Research Center, \\ T. W. Seamans \\ USDA/APHIS/WS National Wildlife Research Center, thomas.w.seamans@aphis.usda.gov \\ C.P. Dwyer \\ US Department of Agriculture, National Wildlife Research Center,
}

Follow this and additional works at: https://digitalcommons.unl.edu/icwdm_usdanwrc

Part of the Environmental Sciences Commons

Belant, J. L.; Seamans, T. W.; and Dwyer, C.P., "Evaluation of propane exploders as white-tailed deer deterrents" (1996). USDA National Wildlife Research Center - Staff Publications. 617.

https://digitalcommons.unl.edu/icwdm_usdanwrc/617

This Article is brought to you for free and open access by the U.S. Department of Agriculture: Animal and Plant Health Inspection Service at DigitalCommons@University of Nebraska - Lincoln. It has been accepted for inclusion in USDA National Wildlife Research Center - Staff Publications by an authorized administrator of DigitalCommons@University of Nebraska - Lincoln. 


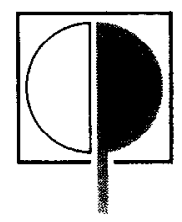

\title{
Evaluation of propane exploders as white-tailed deer deterrents
}

\author{
J. L. Belant*, T. W. Seamans and C. P. Dwyer ${ }^{t}$ \\ US Department of Agriculture, National Wildife Research Center, 6100 Columbus Avenue, \\ Sandusky, $\mathrm{OH} 44870$, USA
}

\begin{abstract}
In response to increased white-tailed deer (Odocoileus virginianus) depredation of agricultural crops and encroachment on airports, we evaluated the effectiveness of systematic and motion-activated propane exploders as deer frightening devices. We conducted three experiments in a 2200 ha fenced facility in northern Ohio with high $\left(91 / \mathrm{km}^{2}\right)$ deer densities during 1994-1995. Systematic exploders were calibrated to detonate once at 8 to $10 \mathrm{~min}$ intervals, whereas motion-activated exploders detonated 8 times/deer intrusion. Systematic propane exploders were generally ineffective, deterring deer from corn for $\leqslant 2$ days only, whereas motion-activated exploders repelled deer for $0-6$ weeks. Repellency of motionactivated exploders varied seasonally, possibly in response to variations in deer density, availability of alternate food, or reproductive and social behavior. We recommend motion-activated exploders over systematic exploders as deer frightening devices for crop damage mitigation and on airports; however, systematic exploders may have utility for short-term (a few days) use. Published by Elsevier Science Ltd.
\end{abstract}

Kerwords: Odocoileus virginianus; propane exploder; deterrent; white-tailed deer

White-tailed deer (Odocoileus virginianus) populations in the United States have increased dramatically in recent years. Deer can cause severe economic loss to agricultural crops (Scott and Townsend, 1985; Dudderar et al., 1990; Sayre and Decker, 1990). A survey of agricultural producers by the U.S. Department of Agriculture (USDA) determined that white-tailed deer was the species most frequently implicated in causing crop damage in the eastern United States (Wywialowski and Beach, 1992). Agricultural and wildlife agencies similarly ranked deer (Odocoileus spp.) as causing more crop damage overall than any other group of wildlife (Conover and Decker, 1991).

Increasing deer populations in many urban areas have resulted in their increased use of airports (Bashore and Bellis, 1982). Airports frequently contain large expanses of grasses and forbs that provide high-quality forage for deer. Deer are of concern to aviation safety as they are responsible for $65 \%$ of aircraft-mammal collisions (Frankenfield et al., 1994).

Numerous techniques, including fences, lethal control and repellents have been developed and employed in efforts to deter deer from these agricultural and nonagricultural situations (Caslick and Decker, 1979; Palmer et al., 1985; Hygnstrom and Craven, 1988; Andelt et al., 1991; Montoney, 1994). Propane exploders are another device used to repel numerous vertebrate species, including deer (Craven and

*Author to whom correspondence should be addressed

†Present address: Missouri Department of Conservation, PO Box 356, Atlanta, MO 63530, USA
Hygnstrom, 1994); however, the duration and degree of their effectiveness has not been evaluated adequately (Bomford and O'Brien, 1990).

Exploders have generally been designed to detonate at standard time intervals (Stickley et al., 1972; Cummings et al., 1986), but are likely more effective when calibrated to detonate at random intervals (Bomfort and O'Brien, 1990). Motion-activated exploders using automatic detection devices are currently being developed. As motion-activated exploders detonate only when the target species approaches the area to be protected, habituation may not occur as rapidly as with exploders activated at predetermined or random intervals. Our objective was to compare the duration and degree of effectiveness of systematic (detonated at predetermined intervals) and motion-activated propane exploders as white-tailed deer deterrents.

\section{Materials and methods}

The study was conducted during 1994-1995 at the National Aeronautic and Space Administration Plum Brook Station (PBS), Erie County, Ohio. This 2200 ha facility is enclosed by a $2.4 \mathrm{~m}$ chain-link fence with barbed-wire outriggers. Habitats within PBS consist primarily of grasslands, wooded grasslands and mixed hardwood forests (Rose and Harder, 1985). During this study, PBS contained an estimated white-tailed deer population of about 2000 (91 deer $/ \mathrm{km}^{2}$ ) (E. C. Cleary, USDA, pers. commun.). The deer herd was 
last hunted in autumn 1992, when 900 deer were harvested on 10 days during a 5 week period.

Six feeding sites $>1 \mathrm{~km}$ apart were established in grasslands at PBS. For each experiment, we erected approximately $100 \mathrm{~m}$ of $1.5 \mathrm{~m}$ high plastic fence in a semi-circle at each of 3 sites and placed $23 \mathrm{~kg}$ of wholekernel corn in a $1 \mathrm{~m}$ circle at the center of the arc 2-4 m from the fence. Fences limited access of deer to corn from one direction only. A nonfunctioning propane exploder (Scare Away cannon, Reed Joseph, Inc., Greenville, MS) was placed at each station 3-5 m from the bait on the opposite side of the fence. An electronic detecting device with automatic counter [Ground Intercept System (GIS), Field Systems 1, Inc., Huron, S.D.] was placed at one end of each fence and directed toward the opposite end. Thus, deer entering or leaving each site would be recorded by the GIS. We attempted to direct the detection field of the GIS to avoid recording non-target animals [e.g. raccoons (Procyon lotor)]. Exploders were positioned opposite the bait to reduce the possibility of deer disrupting the wires connecting the propane exploder to the GIS. To condition deer to use feeding sites we monitored each site daily for 1 month prior to each experiment, recording the number of intrusions and providing corn as needed. To reduce the potential for habituation by deer, treatments were alternated among the same feeding sites between Experiments 1 and 2; the three remaining feeding sites were used during Experiment 3 .

We conducted three experiments: 9 August-12 September 1994 (late summer), 20 September-24 October 1994 (autumn) and 27 April-12 July 1995 (spring/early summer). Each experiment consisted of a 2-week pretreatment period followed by a 3-9 week post-treatment period. Experiments were discontinued when it was determined that the exploders had been ineffective for $\geqslant 2$ weeks. During each experiment, three sites were assigned randomly to one each of three treatments consisting of a systematic, motion-activated, or nonfunctioning (control) exploder. Systematic exploders were set to detonated once every 8-10 min, irrespective of deer presence at feeding sites. Motionactivated exploders were arbitrarily set to detonate eight times in $2 \mathrm{~min}$ ( 1 detonation $/ 15 \mathrm{~s}$ ) about $10 \mathrm{~s}$ after a deer was detected by the GIS. After detonation, the motion-activated exploder was inactive until a deer was again detected. For each experiment, we recorded the daily number of deer intrusions/treatment and provided corn as needed. Propane exploders were not moved during experiments.

For each site during each experiment, we calculated the mean daily number of deer intrusions/week. We used analysis of variance (ANOVA) (General Linear Models Procedure; SAS Institute, Inc., 1988) with repeated measures (weeks) to compare the number of deer intrusions among weeks. If main effects were significant $(P<0.05)$, we used Tukey tests to determine which means differed. Because we were unable to achieve statistically valid replication for treatments, we used ANOVA without replication (Zar, 1984), and did not test for the interaction of week and type of propane exploder. Although we recognize the importance of experimental replication, because of human activity and the need to space experimental sites $>1 \mathrm{~km}$ apart to maintain independence, statistically valid replications of treatments used were logistically impossible to achieve within the confines of PBS.

\section{Results}

\section{Experiment 1, late summer}

The number of intrusions at each sitc differed $(F=3.90-15.90 ; 1,4 \mathrm{df} ; \quad P<0.02)$ among weeks (Figure 1). The motion-activated exploder reduced $(P<0.05)$ the mean number (ISE) of intrusions by $63 \%$ during week 1 post-treatment (94 \pm 39$)$ compared to pretreatment levels $(251 \pm 72)$; however, intrusions during week 2 post-treatment $(239 \pm 49)$ were comparable to pretreatment intrusion rates. Compared with mean daily pretreatment intrusions $(183 \pm 43)$, deer intrusions at the systematic exploder were greater $(P<0.05)$ during weeks $1-2$ posttreatment $(346 \pm 32)$. However, the mean number of intrusions at the systematic exploder during days 1-2 post-treatment $(\bar{x}=94)$ was $54 \%$ less than the mean number of intrusions during pretreatment $(\overline{\mathrm{x}}=206)$. Intrusions declined $(P<0.05)$ during week 3 posttreatment $(230 \pm 18)$ but remained higher than pretreatment levels. Variation at the control site was due primarily to high intrusion rates during week 1 pretreatment $(617 \pm 33)$ and week 2 post-treatment (556 \pm 56).

On average, the motion-activated exploder detonated 1856 times/day (11.6 detonations/9 min), 11.6 times more often than the systematic exploder detonated each day.

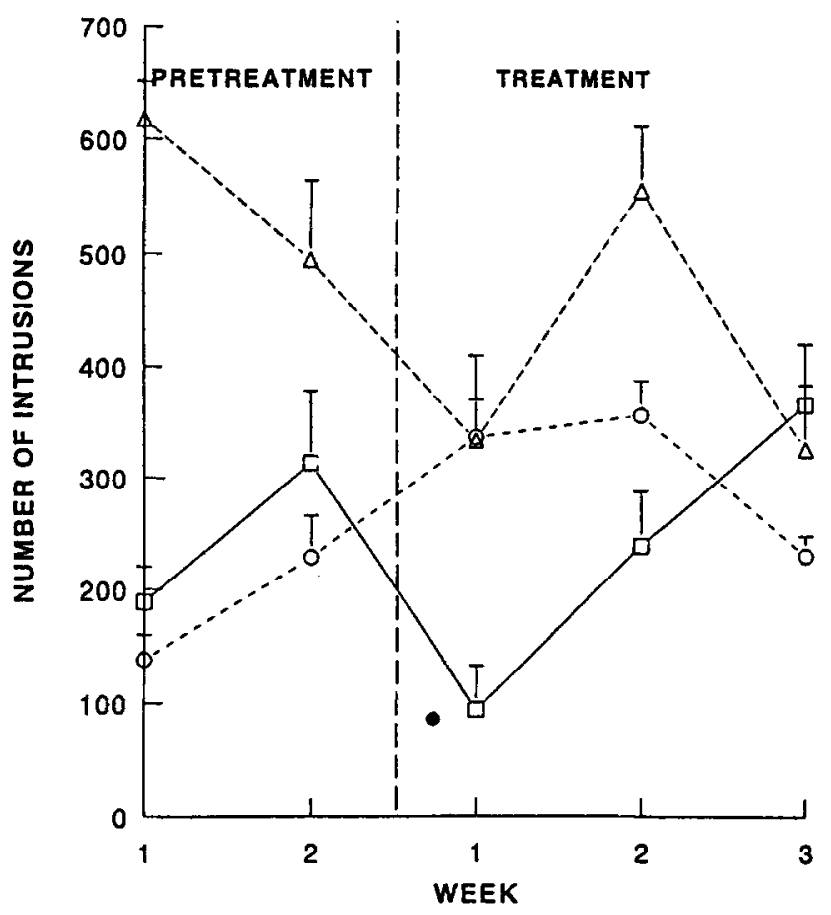

Figure 1. Mean daily number of white-tailed deer intrusions at site with motion-activated exploder (square symbols), systematic exploder (circles), and nonfunctioning exploder (triangles) by week, Plum Brook Station, Erie County, Ohio, 10 August-12 September 1994. Solid circle represents the mean number of intrusions at the systematic exploder during days 1-2 posttreatment. Capped vertical lines denote standard errors 


\section{Experiment 2, autumn}

The number of intrusions at the control and motionactivated exploder sites differed $(F=5.86$ and 9.00; $1,4 \mathrm{df} ; P<0.02$ ) among weeks (Figure 2). Variation in intrusions at the control site was due primarily to 27 and $41 \%$ decreases occurring during week 2 pretreatment and week 3 post-treatment, respectively. The motion-activated exploder did not reduce $(P>0.05)$ the number of deer intrusions during post-treatment. This effect was a consequence of a $55 \%$ reduction in intrusions occurring between weeks $1-2$ pretreatment. Mean daily deer intrusions at the systematic exploder site during pretreatment and post-treatment were similar $(F=1.14 ; 1,4 \mathrm{df} ; P<0.37)$. However, the mean number of intrusions at the systematic exploder during days $1-2$ post-treatment $(\overline{\mathrm{x}}=114)$ was $44 \%$ less than the mean number of intrusions during pretreatment $(\bar{x}=202)$. In contrast, the mean number of intrusions during days $1-2$ post-treatment $(\bar{x}=191)$ at the motion-activated exploder decreased $5 \%$ only from a mean of $200 /$ day intrusions during pretreatment.

On average, the motion-activated exploder detonated 2200 times/day (13.8 detonations/9 min), 13.8 times more often than the systematic exploder detonated each day.

\section{Experiment 3, spring/early summer}

The number of intrusions at the motion-activated and systematic exploder sites differed $(F=10.54$ and 4.69 ;

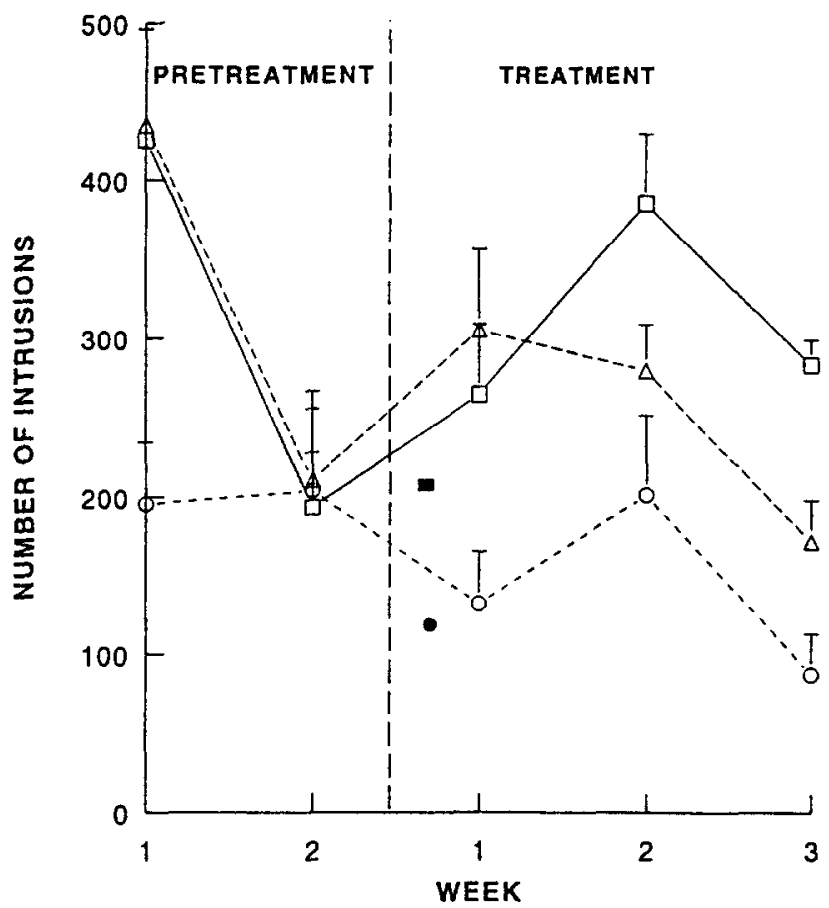

Figure 2. Mean daily number of white-tailed deer intrusions at site with motion-activated exploder (square symbols), systematic exploder (circles), and nonfunctioning exploder (triangles) by week, Plum Brook Station, Erie County, Ohio, 21 September24 October 1994. Solid square and circle represent the mean number of intrusions at the motion-activated and systematic exploder, respectively, during days 1-2 post-treatment. Capped vertical lines denote standard errors

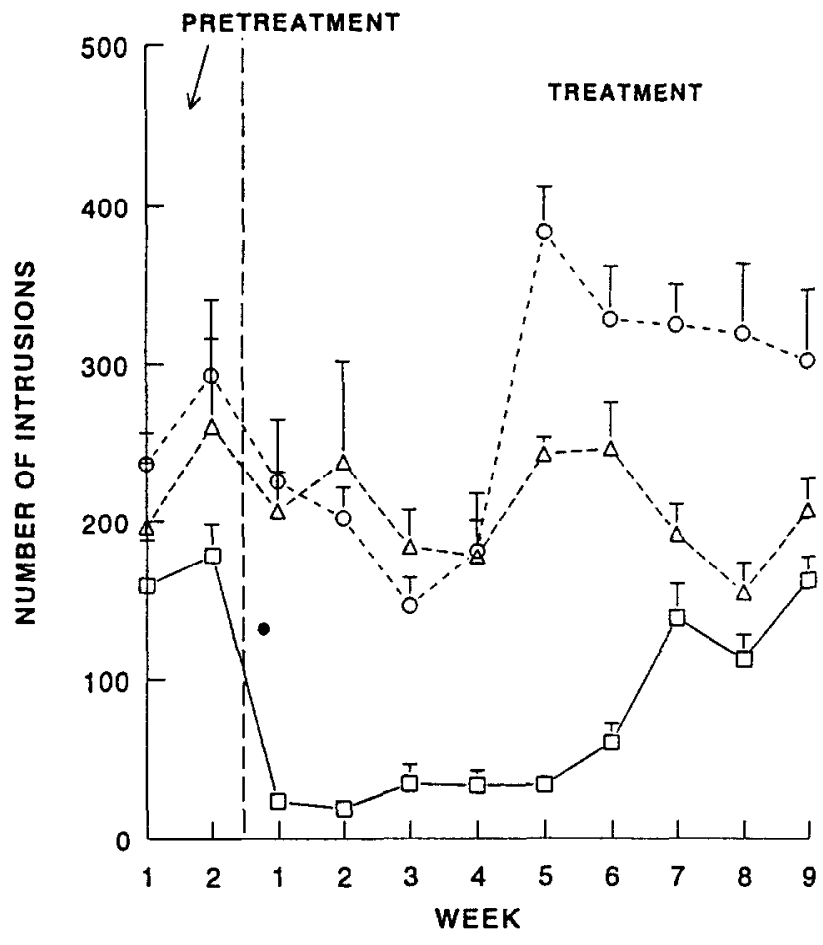

Figure 3. Mean daily number of white-tailed deer intrusions at site with motion-activated exploder (square symbols), systematic exploder (circles), and nonfunctioning exploder (triangles) by week, Plum Brook Station, Erie County, Ohio, 27 April-12 July 1995. Solid circle represents the mean number of intrusions at the systematic exploder during days 1-2 post-treatment. Capped vertical lines denote standard errors

$1,10 \mathrm{df} ; P<0.01$, respectively) among weeks (Figure $3)$. The motion-activated exploder reduced the daily mean number of intrusions by $80 \%$ for 6 weeks $(34 \pm 20)$ relative to pretreatment levels $(168 \pm 36)$. In contrast, the number of intrusions at the systematic exploder site during weeks $1-4$ post-treatment generally remained similar to pretreatment levels, than increased and stabilized during weeks 5-9. Although the systematic exploder was ineffective overall during posttreatment, the mean number of intrusions during days $1-2$ post-treatment $(\overline{\mathrm{x}}=132)$ was $53 \%$ less than the mean number of intrusions during pretreatment $(\bar{x}=279)$. The number of intrusions at the control site was similar $(F=0.93 ; 1,10$ df; $P=0.51)$ among weeks.

On average, the motion-activated exploder detonated 675 times/day (4.2 detonations/9 $\mathrm{min}$ ), 4.2 times more often than the systematic exploder detonated each day.

\section{Discussion}

Propane exploders are often suggested as effective frightening agents for deer (Craven and Hygnstrom, 1994), and have been used frequently in attempts to reduce crop damage and encroachment on airports. Our results suggest that stationary propane exploders that detonate systematically at $8-10 \mathrm{~min}$ intervals are effective in frightening deer for 2 days only. In contrast, motion-activated propane exploders were effective for $0-6$ weeks, showing dramatic variation among seasons. 
Because of the predictability of detonation, we believe that habituation occurred more rapidly at sites with systematic exploders than at sites with motionactivated exploders. Although motion-activated exploders likely reduced habituation by detonating only when deer were present, the large number of shots fired/intrusion (8) may have reduced its effectiveness overall. Motion-activated exploders detonated 4-14 times more often each day than did systematic exploders during this study. Reducing the number of explosions by the motion-activated exploder/intrusion may enhance effectiveness by further reducing habituation. Total operating costs would simultaneously be reduced.

Our data demonstrated spatial and temporal variability of deer use of specific feeding sites within and among experiments which confounds interpretation of data. Variation of intrusion rates could be a consequence of several factors including availability of alternate food, relative deer density, and social or reproductive behaviour. Although we did not achieve experimental replication, we believe our results accurately reflect the relative effectiveness of the two propane exploder detonation systems used (Bomford and O'Brien, 1990).

The unusually high deer density $\left(91 / \mathrm{km}^{2}\right)$ observed during this study probably resulted in conservative estimates of deer deterrence by propane exploders. Effectiveness of exploders is dependent in part on intensity of deer use of the area being protected, repellency in other areas will likely be greater than repellency observed in this study. Operating exploders when damage first occurs, moving exploders frequently and elevating exploders to increase noise levels may also enhance their effectiveness (Craven and Hygnstrom, 1994).

We recommend motion-activated exploders over systematic exploders as deer deterrents for crop damage mitigation and at airports. Motion-activated exploders are more likely than systematic exploders to reduce deer damage over a several-week period of crop susceptibility (e.g. sprouting-early growth stage in soybeans). Systematic exploders, however, may have utility for short-term (a few days) use. As with other vertebrate deterrents, incorporation of additional control techniques are likely to be necessary to maximize effectiveness of propane exploders (US Department of Agriculture, 1993).

\section{Acknowledgments}

A. L. Bower, PBS, granted permission to use study sites; J. B. Schumacher, Field Systems 1 Corp., designed and provided GIS units. E. C. Clcary provided propane exploders and helpful suggestions for study design. We thank G. E. Bernhardt, H. A. Bolte, R. A. Deering, R. A. Dolbeer, S. W. Gabrey, J. C. Hovis, S. K. Ickes, K. D. Madaras, E. J. Marshall, M. R. Rutger, L. A. Tyson, and S. R. Zieber for field assistance. R. A. Dolbeer assisted with study design and critically reviewed an earlier draft of this manuscript. Sponsorship and funds for this research were provided by the Federal Aviation Administration (FAA), Office of Airports Safety and Standards,
Washington D.C., and Airports Division, Airport Technology Branch, FAA Technical Center, Atlantic City International Airport, New Jersey.

\section{References}

Andelt, W. F., Burnham, K. P. and Manning, J. A. (1991) Relative effectiveness of repellents for reducing mule deer damage. J. Wildl. Marage. 55, 341-347

Bashore, T. L. and Bellis, E. D. (1982) Deer on Pennsylvania airfields: problems and means of control. Wildl. Soc. Bull. 10, 386-388

Bomford, M. and O'Brien, P. H. (1990) Sonic deterrents in animal damage control: a review of device tests and effectiveness. Wildl. Soc. Bull. 18, 411-422

Caslick, J. W. and Decker, D. J. (1979) Economic feasibility of a deer-proof fence for apple orchards. Wildl. Soc. Bull. 7, 173-175

Conover, M. R. and Decker, D. J. (1991) Wildlife damage to crops: perceptions of agricultural and wildlife professionals in 1957 and 1987. Wildl. Soc. Bull. 19, 46-52

Craven, S. K. and Hygnstrom, S. E. (1994) Deer. In: Prevention and Control of Wildl. Damage. (Ed. by S. E. Hygnstrom, R. M. Timm and G. E. Larson), pp. D25-D40. Univ. Nebraska Coop. Ext. Serv., Lincoln, USA

Cummings, J. L., Knittle, C. E. and Guarino, J. L. (1986) Evaluating a pop-up scarecrow coupled with a propane exploder for reducing blackbird damage to ripening sunflower. Proc. Vertebr. Pest Conf. 12, 286-291

Dudderar, G. R., Haufler, J. B., Winterstein, S. R. and Gunarso, P. (1990) GIS: a tool for analyzing and managing deer damage to crops. Proc. East. Wildl. Damage Control Conf. 5, 182-197

Frankenfield, D. L., LeBoeuf, E., Floyd, J., Lange, W. R. and Baker, S. P. (1994) Animal ambush at the airport: wildlife hazards in U.S. aviation, 1983-1993. Spec. Rep., Johns Hopkins Univ., School Publ. Health, Cent. for Injury Res. and Policy. Baltimore, Maryland, $17 \mathrm{pp}$

Hygnstrom, S. E. and Craven, S. R. (1988) Electric fences and commercial repellents for reducing deer damage in cornfields. Wildl. Soc. Bull. 16, 291-296

Montoney, A. J. (1994) White-tailed deer management program at O'Hare International Airport. Bird Strike Committee USA 4, 20

Palmer, W. L., Payne, J. M., Wingard, R. G. and George, J. L. (1985) A practical fence to reduce deer damage. Wildl. Soc. Bull. 13, 240-245

Rose, J. and Harder, J. D. (1985) Seasonal feeding habits of an enclosed high density white-tailed deer herd in northern Ohio. Ohio J. Sci. 85, 184-190

SAS Institute, Inc. (1988) SAS/STAT user's guide, SAS Institute, Inc., Cary, North Carolina, $1028 \mathrm{pp}$

Sayre, R. W. and Decker, D. J. (1990) Extent and nature of deer damage to commercial nurseries in New York. Proc. East. Wildl. Damage Control Conf. 5, 162-172

Scott, J. D. and Townsend, T. W. (1985) Decr damage and damagc control in Ohio's nurseries, orchards and Christmas tree plantings. Proc. East. Wildl. Damage Control Conf. 2, 83-88

Stickley, A. R., Mitchell, R. T., Heath, R. B., Ingram, C. R. and Bradley, E. L. (1972) A method for appraising the bird repellency of 4-aminopyridine. $J$. Wildl. Manage. 36, 1313-1316

US Department of Agriculture (1993) ADC airport safety manual. US Dep. Agric., Animal and Plant Health Inspect. Serv., Animal Damage Control, Washington, D.C., 245 pp

Wywialowski, A. P. and Beach, R. H. (1992) Agricultural producers' estimates of wildlife causing damage in eastern states. (Abstr.) Proc. East. Wildl. Damage Control Conf. 5, 66

Zar, J. H.(1984) Biostatistical analysis, Second ed., Prentice Hall, Englewood Cliffs, New Jersey, 718 pp

Submitted 5 December 1995

Accepted 7 February 1996 